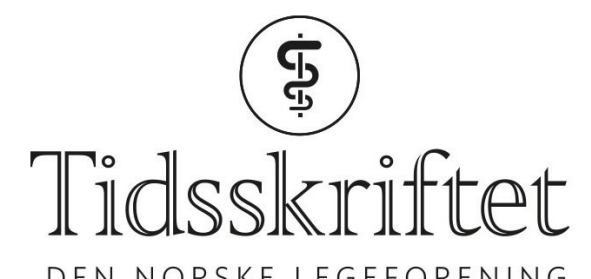

DEN NORSKE LEGEFORENING

\title{
Kritikk av ondartet kreftpolitikk
}

ANMELDELSER

EIRIK JOAKIM TRANVÅG

Lege og doktorgradsstipendiat, Bergen senter for etikk og prioritering Universitetet i Bergen

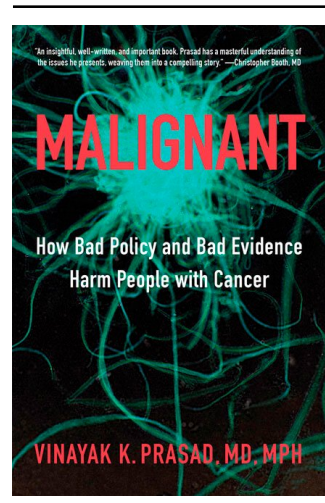

Vinayak K. Prasad

Malignant

How Bad Policy and Bad Evidence Harm People with Cancer. 304 s, ill. Baltimore, MD: Johns Hopkins University Press, 2020. Pris NOK 399

ISBN 978-1-4214-3763-7

Denne boken handler ikke om kreftbiologi, den handler om kreftpolitikk. Mens det fortsatt gjenstår mye arbeid før vi fullt ut forstår den komplekse biologien og genetikken som ligger bak kreftsykdommer, er politikken rundt forskning, utvikling og godkjenning av kreftlegemidler derimot helt og holdent under menneskelig kontroll. Likevel, argumenterer forfatteren, lider kreftpasienter unødvendig av et ondartet og dysfunksjonelt økosystem for kreftlegemidler.

Vianyak K. Prasad er onkolog og førsteamanuensis ved University of California, San Francisco, og har i sosiale medier de siste årene etablert seg som en skarp kritiker av kreftpolitikk, kliniske studier og legemiddelgodkjenninger. De som følger han, vil kjenne igjen den direkte tonen og kompromissløse stilen. Noen, undertegnede inkludert, vil nok synes at boken hadde hatt godt av en mildere og mer balansert fremstilling. Referansene til egne studier er hyppige. Men det er likevel vanskelig å være uenig med Prasad. På en enkel og lettfattelig måte viser han i bokens to første deler hvordan dårlige kliniske studier, $\emptyset$ konomiske interessekonflikter og svak regulering av utvikling og godkjenning av legemidler er dårlig kreftpolitikk som skader kreftpasienter.

I tredje del gir Prasad en enkel innføring i hvordan man skal tolke evidens og kliniske 
studier. Dette er nyttig. I fjerde og siste del kommer han med forslag til hvordan systemet kan forbedres, og her kommer også de store forskjellene mellom norsk og amerikansk kontekst frem. Prasad ønsker en sterkere offentlig regulering av kreftpolitikken. Noen av forslagene er radikale, selv i en norsk målestokk. For eksempel mener han at myndighetene selv bør designe og utføre kliniske studier. Mange av forslagene er likevel selvsagte for oss i Norge. Vi har allerede et system, Nye metoder, der vi evaluerer kliniske studier, setter krav til evidens og effekt, legger til rette for konkurranse, forhandler om pris m.m.

Jeg anbefaler boken til alle som er interessert i en lettfattet innføring i amerikansk kreftpolitikk og legemiddelgodkjenning, og kanskje spesielt til de som er engasjert i hvordan Beslutningsforum jobber. Slik det globale systemet for utvikling av legemidler er i dag, er boken relevant også for oss her i Norge.

Publisert: 9. november 2020. Tidsskr Nor Legeforen. DOI: 10.4045/tidsskr.20.o6o1

(C) Tidsskrift for Den norske legeforening 2020. Lastet ned fra tidsskriftet.no 